\title{
Evaluation of Knowledge, Attitude and Practices of Nurses Regarding Professionalism in Main Primary Health Care (PHC) Centers and Hospitals in Erbil City/Iraq
}

Kareem Fattah Aziz ( $\nabla$ kareem.azeez@hmu.edu.krd)

Hawler Medical University https://orcid.org/0000-0002-3195-9199

Yousif Bahadin

Hawler Medical University College of Medicine

Moslih Saber kareem

Hawler Medical University

Research article

Keywords: knowledge, attitude, practices, nurses, professionalism, hospital

Posted Date: June 3rd, 2020

DOI: https://doi.org/10.21203/rs.3.rs-30537/v1

License: (c) (1) This work is licensed under a Creative Commons Attribution 4.0 International License.

Read Full License 


\title{
Evaluation of Knowledge, Attitude and Practices of Nurses Regarding Professionalism in Main Primary Health Care (PHC) Centers and Hospitals in Erbil City/Iraq
}

\author{
corresponding author: Assist. Prof. Dr. Kareem F. Aziz \\ Email: drkareem2009@gmail.com Phone Number:+9647504549298 \\ Assist.Prof Dr.Yousif Bahadin \\ Email: you_xati@yahoo.com Phone Number: +9647504680313 \\ Moslih Saber kareem \\ Email: mosleh.saber@yahoo.com Phone Number: +9647504773050
}

\begin{abstract}
:
Background and objectives: The term 'professionalism' refers to the conduct, qualities, and goals that characterize a profession and usually describes behaviors that are expected of the members of the profession. Healthcare suppliers demonstrate expertise by attitudes, knowledge, and behaviors that reflect a multi-faceted approach to the regulations, principles, and standards underlying successful clinical practices. The objective of this study is to identify knowledge, practices and attitudes of nurses regarding professionalism and to identify association between variables and (knowledge, practices, attitudes) of nurses regarding professionalism.

Methods: Research design: it is a descriptive cross sectional design. The study conducted in main primary health care centers and hospitals in Erbil city. The study was conducted from 1-6-2018 to 1-10-2018. Non- probability sampling technique was done for data collection, the estimated sample size included (100) nurses out of 400 nurses who work in health care centers and hospitals. Data were collected with interview technique with nurses, using the standardized questionnaire. The questionnaire consists of four main parts. The data was analyzed through the application of SPSS program version 23. (Statistical Package for social Science),

Results: The results of this study revealed that majority of nurses have (44\%) fair knowledge (50\%) fair practices and (87\%) fair attitudes regarding professionalism and also there was significant association between their level of education and professionalism about (knowledge, practices and attitudes) which represented $(\mathrm{P}-\mathrm{Value}=0.001)$ while there was not significant association between other variables and professionalism as for knowledge, practice and attitude ( $\mathrm{P}$-value $<0.05$ ).

Conclusion: The outcomes of this study revealed that majority of nurses have fair knowledge, practices and attitudes regarding professionalism and also there was significant association between their level of education and professionalism while there was not significant association between other variables and professionalism.
\end{abstract}

Keywords: knowledge, attitude, practices, nurses, professionalism, hospital. 


\section{Background}

The professionalism in nursing is essential to practice nursing services. Nurses put themselves in positions of trust each and every day, and therefore it is essential that the people that rely on the care of nurses are confident that they are being cared for by professionals. There are barriers to professionalism in the nursing, but they can be overcome if nurses work together toward a common goal. Nursing educators and leaders need to emphasize the fact that they can establish professional tendencies that will follow them throughout their career [1]. Nurses have a task to play in making professionalism; there square measure some barriers that substitute the approach. One of the most important barriers could be a distinction in academic background among nurses. Different nurses have different levels of education, but nurses ought to work to minimize the effects of educational disparity among them. Further, gender problems will function a barrier to expertness. Nursing has long been thought of as female-dominated (or "women's work"), but now more than ever, men are entering the profession, and equality among the sexes in the profession is something that may serve to extend expertness still. These square measure simply 2 of main barriers that substitute the approach of expertness in nursing, however these barriers et al don't substitute the approach of expertness, rather they are just reasons for nurses to work harder for the benefit of the reputation of their profession [2]. The term 'professionalism' refers to the conduct, qualities, and goals that characterize a profession and usually describes behaviors that are expected of the members of the profession. Healthcare suppliers demonstrate expertise by attitudes, knowledge, and behaviors that reflect a multi-faceted approach to the regulations, principles, and standards underlying successful clinical practices [3]. Professionalism is a multi-dimensional concept that provides nurses with opportunities to grow personally and professionally Professionalism in nursing results in enhanced patient care and greater job satisfaction among nurses, and nurse retention $[4,5]$. Professionalism in nursing has not been without its challenges from inception to today. These challenges include educational preparation, diversity in the nursing population, lack of leadership skills, and the nature of the job. It is only through identification and continued work to resolve these conflicts that nursing will proceed to gain the full recognition and respect of a profession [6-7]. In 1971 Ronald M. Pavalko offered eight dimensions to describe a profession. This scale allows professions to exhibit various degrees of these attributes and possess most, if not all, of these dimensions [8-9]. These are theoretical framework as a basis for practice, relevance to social values, (educational) period, autonomy, commitment to lifelong work, a common identity and distinctive subculture, a code of ethics [10, 11]. Nurses demonstrating the attributes of expertise impact completely on patient satisfaction and health outcomes [12, 13, and 14]. This study was conducted to identify knowledge, practices and attitudes of nurses regarding professionalism and association between variables and (knowledge, practices, 
attitudes) of nurses regarding professionalism.

\section{Methods:}

\section{The aim of the study:}

Is to identify levels of nurses regarding professionalism; it is a descriptive cross sectional design. The study conducted in main primary health care centers and hospitals in Erbil city, achieved from 1-62018 to $1-10-2018$.

\section{Sample of the study:}

Non- probability sampling technique was done for data collection, the estimated sample size included (100) nurses out of (400) nurses who work in primary health care centers and hospitals. The sample size was calculated by using the statistical formula as: Sample size estimation// Sample size $=Z^{2} \mathrm{pq} / \mathrm{d}^{2}$.

$\mathrm{z}=$ confident interval 95\% (1.96)

$\mathrm{p}=$ prevalence $(0.32)$

$\mathrm{q}=(1-\mathrm{p})=(0.81)$

$\mathrm{d}=$ sampling error $(0.05)$

\section{Inclusion criteria:}

1. Nurses who work in PHC Centers and hospitals.

2. Nurses who have desire to participate in this study.

\section{Exclusion criteria:}

Nurses who have not desire to participate in this study.

\section{Tools and methods of data collection:}

Data were collected with interview technique with nurses, using the standard questionnaire. The questionnaire consists of four main parts. Part one is related to socio demographic characteristics of them which was included (age, address, marital status, sex, Level of education, economic status and experience by year). Second part consists of statements related to nurses' knowledge about professionalism and the answers were divided in two categories of scoring system as ( 1 for yes and 2 for no ) Part three included items related to nurse's practice about professionalism so the answers were divided two categories of scoring system as ( 1 for done and 2 for never done) Part four included questions related to attitudes so the answers were divided in two category of scoring system as (1 for positive and 2 for negative attitudes). The tool was viewed to panel of experts in nursing field for validity. The likert scale was used for preparing the questionnaire. [15]. The researcher has taken the permission from the ethical committee in the research center in howler medical university, general directorate of health and main PHC Centers and hospitals in 
Erbil city. The researcher promised to keep the information confidential, and use these data for this study only, then he explained the purposes of this study to each nurses before collection the data.

\section{Data analysis:}

The data was analyzed through the application of SPSS program version 23. (Statistical Package for social Science) and included descriptive statistical analysis, frequency and chi-square.

\section{Results:}

Table 1 shown demographic characteristics of sample study as followings: most of them were between 31-40 years old, most of them female, majority of them from urban, most of them from institute, majority of them married, most of them have insufficient economic, and majority of them have more than 2 years of experiences.
Table 1: Demographic Characteristics of Nurses

\begin{tabular}{|c|c|c|c|}
\hline Items & & Frequency & $\%$ \\
\hline \multirow[t]{4}{*}{ Age groups } & 21 - 30 Years old & 39 & $39 \%$ \\
\hline & 31 - 40 Years old & 42 & $42 \%$ \\
\hline & 41 - 55 Years old & 19 & $19 \%$ \\
\hline & Total & 100 & $100 \%$ \\
\hline \multirow[t]{3}{*}{ Sex } & Male & 22 & $22 \%$ \\
\hline & Female & 78 & $78 \%$ \\
\hline & Total & 100 & $100 \%$ \\
\hline \multirow[t]{4}{*}{ Address } & Urban & 63 & $63 \%$ \\
\hline & Suburban & 23 & $23 \%$ \\
\hline & Other Place & 14 & $14 \%$ \\
\hline & Total & 100 & $100 \%$ \\
\hline \multirow[t]{4}{*}{ Level Education } & Nursing School & 20 & $20 \%$ \\
\hline & Institute & 53 & $53 \%$ \\
\hline & College & 27 & $27 \%$ \\
\hline & Total & 100 & $100 \%$ \\
\hline \multirow[t]{4}{*}{ Marital Status } & Single & 25 & $25 \%$ \\
\hline & Married & 64 & $64 \%$ \\
\hline & Widow & 11 & $11 \%$ \\
\hline & Total & 100 & $100 \%$ \\
\hline \multirow[t]{4}{*}{ Economic Status } & Sufficient & 24 & $24 \%$ \\
\hline & Fair & 18 & $18 \%$ \\
\hline & Insufficient & 58 & $58 \%$ \\
\hline & Total & 100 & $100 \%$ \\
\hline \multirow{4}{*}{$\begin{array}{l}\text { experience by } \\
\text { year }\end{array}$} & One year & 8 & $8 \%$ \\
\hline & Two years & 14 & $14 \%$ \\
\hline & $\begin{array}{l}\text { More than two } \\
\text { years }\end{array}$ & 78 & $78 \%$ \\
\hline & Total & 100 & $100 \%$ \\
\hline
\end{tabular}

Table 2 showed the levels of nurse's knowledge about professionalism so most of them have fair knowledge which represented $44 \%$.

Table 2: Levels of Nurses' Knowledge about Professionalism 


\begin{tabular}{lcc}
\hline \multicolumn{1}{c}{ Items } & Frequency & $\%$ \\
\hline Low level of Knowledge & 15 & $15 \%$ \\
Fair level of Knowledge & 44 & $44 \%$ \\
Good level of Knowledge & 41 & $41 \%$ \\
Total & 100 & $100 \%$
\end{tabular}

Table 3 shown levels of practice for nurses so majority of them have fair practice about professionalism which represented 50\%.

Table 3: Levels of Nurses' Practice about Professionalism

\begin{tabular}{lcc}
\hline \multicolumn{1}{c}{ Items } & Frequency & $\%$ \\
\hline Low level of Practice & 15 & $15 \%$ \\
Fair level of Practice & 50 & $50 \%$ \\
Good level of Practice & 35 & $35 \%$ \\
Total & 100 & $100 \%$
\end{tabular}

$\overline{\text { Table } 4 \text { shown levels of attitudes of nurses about }}$ professionalism so majority of them have fair attitudes which represented $87 \%$.

Table 4: Types of Attitude of Nurses about Professionalism

\begin{tabular}{lcc}
\hline \multicolumn{1}{c}{ Items } & Frequency & $\%$ \\
\hline Low level of Attitude & 13 & $13 \%$ \\
Fair level of Attitude & 87 & $87 \%$ \\
Total & 100 & $100 \%$ \\
\hline Table 5 shown there was significant association \\
between education level of nurses and \\
professionalism which represented $0.00 \%$ while \\
there was no significant association between \\
other variables and professionalism.
\end{tabular}

Table 5: Association between Demographical Variables and Levels of Nurses' Knowledge regarding Professionalism

\begin{tabular}{|c|c|c|c|c|c|}
\hline & & $\begin{array}{l}\begin{array}{l}\text { Poor level of } \\
\text { Knowledge }\end{array} \\
\end{array}$ & \begin{tabular}{|l} 
Fair level of \\
Knowledge
\end{tabular} & $\begin{array}{c}\text { Good level of } \\
\text { Knowledge }\end{array}$ & \\
\hline Items & & $\%$ & $\%$ & $\%$ & P Value \\
\hline \multirow[t]{5}{*}{ Groups of Age } & $18-22$ years old & $4 \%$ & $16 \%$ & $19 \%$ & \multirow{5}{*}{0.434} \\
\hline & 23 - 27 years old & $6 \%$ & $21 \%$ & $15 \%$ & \\
\hline & 28 - 37 years old & $5 \%$ & $7 \%$ & $7 \%$ & \\
\hline & Total & $15 \%$ & $44 \%$ & $41 \%$ & \\
\hline & Male & $5 \%$ & $9 \%$ & $8 \%$ & \\
\hline \multirow[t]{2}{*}{ Sex Of Nurses } & $\begin{array}{l}\text { Female } \\
\text { Total }\end{array}$ & $\begin{array}{l}10 \% \\
15 \%\end{array}$ & $\begin{array}{l}35 \% \\
44 \%\end{array}$ & $\begin{array}{l}33 \% \\
41 \%\end{array}$ & \multirow[t]{2}{*}{0.514} \\
\hline & Urban & $12 \%$ & $25 \%$ & $26 \%$ & \\
\hline \multirow{3}{*}{$\begin{array}{l}\text { Address of } \\
\text { Nurses }\end{array}$} & Suburban & $1 \%$ & $13 \%$ & $9 \%$ & \multirow[t]{2}{*}{0.469} \\
\hline & Other Place & $2 \%$ & $6 \%$ & $6 \%$ & \\
\hline & $\begin{array}{l}\text { Total } \\
\text { Preparatory of } \\
\text { Nursing School }\end{array}$ & $\begin{array}{l}15 \% \\
7 \%\end{array}$ & $\begin{array}{l}44 \% \\
9 \%\end{array}$ & $\begin{array}{l}41 \% \\
4 \%\end{array}$ & \multirow{6}{*}{0.000} \\
\hline \multirow{5}{*}{$\begin{array}{l}\text { Level of } \\
\text { Education }\end{array}$} & Institute & $7 \%$ & $31 \%$ & $15 \%$ & \\
\hline & College & $1 \%$ & $4 \%$ & $22 \%$ & \\
\hline & Total & $15 \%$ & $44 \%$ & $41 \%$ & \\
\hline & Single & $3 \%$ & $11 \%$ & $11 \%$ & \\
\hline & Married & $12 \%$ & $25 \%$ & $27 \%$ & \\
\hline \multirow[t]{3}{*}{$\begin{array}{l}\text { Marital Status } \\
\text { Of Nurses }\end{array}$} & Widow & $0 \%$ & $8 \%$ & $3 \%$ & \multirow[t]{3}{*}{0.249} \\
\hline & Total & $15 \%$ & $44 \%$ & $41 \%$ & \\
\hline & Sufficient & $1 \%$ & $13 \%$ & $10 \%$ & \\
\hline \multirow{3}{*}{$\begin{array}{l}\text { Economic status } \\
\text { of Nurses }\end{array}$} & Fair & $6 \%$ & $8 \%$ & $4 \%$ & \multirow{3}{*}{0.067} \\
\hline & Insufficient & $8 \%$ & $23 \%$ & $27 \%$ & \\
\hline & Total & $15 \%$ & $44 \%$ & $41 \%$ & \\
\hline \multirow{4}{*}{$\begin{array}{l}\text { Years of } \\
\text { experience }\end{array}$} & One year & $2 \%$ & $4 \%$ & $2 \%$ & \multirow{2}{*}{0.235} \\
\hline & Two years & $0 \%$ & $5 \%$ & $9 \%$ & \\
\hline & More than two years & $13 \%$ & $35 \%$ & $30 \%$ & \\
\hline & Total & $15 \%$ & $44 \%$ & $41 \%$ & \\
\hline
\end{tabular}


Table 6 shown there was significant association between education level and practice of professionalism which represented $0.001 \%$ while there was no significant association between other variables and professionalism.

Table 6: Association between Demographical Variables and Levels of Nurses' Practice regarding Professionalism

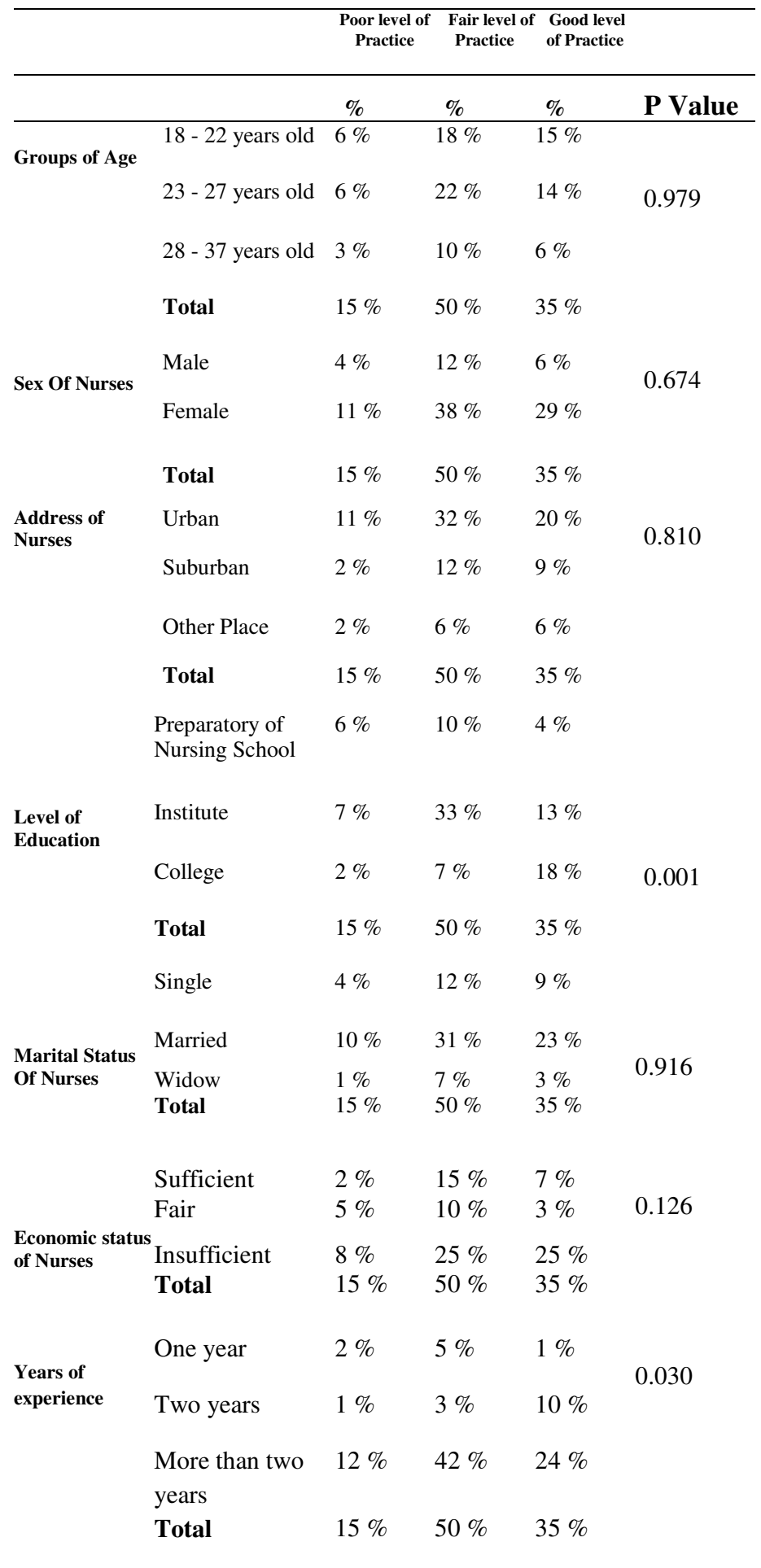

Table 7 shown there was significant association between education level and attitudes about professionalism which represented $0.001 \%$ while there was no significant association 
between other variables and attitudes of professionalism.

Table 7: Association between Demographical Variables and Attitudes about Professionalism

\begin{tabular}{|c|c|c|c|c|}
\hline & & \multicolumn{3}{|c|}{$\begin{array}{l}\text { Poor Good level } \\
\text { level of of } \\
\text { Attitudes Knowledge }\end{array}$} \\
\hline & & $\%$ & $\%$ & P Value \\
\hline \multirow{4}{*}{ Groups of Age } & $18-22$ years old & $2 \%$ & $37 \%$ & \\
\hline & 23 - 27 years old & $5 \%$ & $37 \%$ & 0.018 \\
\hline & 28 - 37 years old & $6 \%$ & $13 \%$ & \\
\hline & Total & $13 \%$ & $87 \%$ & \\
\hline \multirow[t]{3}{*}{ Sex Of Nurses } & Male & $3 \%$ & $19 \%$ & 0.920 \\
\hline & Female & $10 \%$ & $68 \%$ & \\
\hline & Total & $13 \%$ & $87 \%$ & \\
\hline \multirow{5}{*}{$\begin{array}{l}\text { Address of } \\
\text { Nurses }\end{array}$} & Urban & $9 \%$ & $54 \%$ & 0772 \\
\hline & Suburban & $3 \%$ & $20 \%$ & 0.112 \\
\hline & Other Place & $1 \%$ & $13 \%$ & \\
\hline & Total & $13 \%$ & $87 \%$ & \\
\hline & $\begin{array}{l}\text { Preparatory of } \\
\text { Nursing School }\end{array}$ & $6 \%$ & $14 \%$ & \\
\hline \multirow{5}{*}{$\begin{array}{l}\text { Level of } \\
\text { Education }\end{array}$} & Institute & $7 \%$ & $46 \%$ & 0.001 \\
\hline & College & $0 \%$ & $27 \%$ & \\
\hline & Total & $13 \%$ & $87 \%$ & \\
\hline & Single & $2 \%$ & $23 \%$ & \\
\hline & Married & $8 \%$ & $56 \%$ & \\
\hline \multirow[t]{4}{*}{$\begin{array}{l}\text { Marital Status } \\
\text { Of Nurses }\end{array}$} & Widow & $3 \%$ & $8 \%$ & \\
\hline & Total & $13 \%$ & $87 \%$ & \\
\hline & Sufficient & $4 \%$ & $20 \%$ & \\
\hline & Fair & $1 \%$ & $17 \%$ & \\
\hline \multirow[t]{2}{*}{$\begin{array}{l}\text { Economic status } \\
\text { of Nurses }\end{array}$} & Insufficient & $8 \%$ & $50 \%$ & 0.549 \\
\hline & Total & $13 \%$ & $87 \%$ & \\
\hline \multirow{4}{*}{$\begin{array}{l}\text { Years of } \\
\text { experience }\end{array}$} & One year & $0 \%$ & $8 \%$ & \\
\hline & Two years & $1 \%$ & $13 \%$ & 0.366 \\
\hline & $\begin{array}{l}\text { More than two } \\
\text { years }\end{array}$ & $12 \%$ & $66 \%$ & \\
\hline & Total & $13 \%$ & $87 \%$ & \\
\hline
\end{tabular}

\section{Discussion:}

The findings of the study indicated that nurses have three levels of (knowledge, practice and attitudes) regarding professionalism (good, fair and low ) so majority of them have fair knowledge which was represented $44 \%$,they have fair practices which was represented $50 \%$, while they have fair attitudes which was represented $87 \%$ so my opinion about these results included the following interpretations: Nurses have not sufficient knowledge and practices about professionalism therefore it is better to involve all of them with training courses about professionalism, because in every profession standard practice or professionalism is very necessary to decrease nursing errors during their working in hospitals and primary health care centers and to protect patient's right during nursing practices. These findings were disagreed with study done by [16] who said that there was not relationship between education status and their knowledge and practices about professionalism. Other findings of the study indicated that there was significant association between level of education and all three levels of professionalism ( $\mathrm{p}$-value less than 0.05).The interpretation for that is that nurses who have high education level may have more knowledge about professionalism, they work properly and having positive attitudes. These findings were agreed with study done by [17] who 
mentioned that the overall value of nurses regarding the nursing profession is $88 \%$ that is a great result which shows us that most of the nurses have sufficient value about their profession and professionalism. The findings of our study were similar as study done by [18] who mentioned in their study that majority of nurses did not perceive nursing as a dignified and respectful profession to get social recognition. Finally it is necessary to apply professionalism in nursing practices as supported this concept by majority of scientists in nursing field who mentioned in their studies that nurses need strong morals and ethics and the commitment to always act in the best interests of their patients and professionalism among nurses is most important, and nursing educators need to emphasize this fact early, so that nurses can establish professional tendencies that will follow them throughout their practices and patient care[1]. The limitation of the study was included that some of the nurses have not participated in the study.

\section{Conclusion:}

The outcomes of this study revealed that majority of nurses have fair knowledge, practices and attitudes regarding professionalism and also there was significant association between their level of education and professionalism while there was not significant association between other variables and professionalism. The importance of this study includes that nurses working in hospitals and health centers should focus on the application of professional and standard performance for the purpose of decrease errors and maintaining patient safety.

\section{Abbreviations: \\ (PHC) Primary Health Care Center, (SPSS) Statistical Package For The Social Sciences. \\ Acknowledgements: \\ The author would like to thank all nurses who were involved in this study, thanks for all managers and staffs who supported the author to achieve this study.}

\section{Authors' contributions:}

KFA: study design, data collection and analysis, manuscript writing.YB.: study design, data analysis, manuscript writing. MS: manuscript writing and revision. All authors read and approved the final manuscript

\section{Author's information}

Kareem F.Aziz:: Assistant professor in the college of nursing/ hawler medical University $\mathrm{PhD}$ in community health nursing.

Yousif Bahadin.: Assistant professor in the college of Medicine hawler medical University $\mathrm{PhD}$ in Medicine.

Moslih Saber: Lecturer in the college of nursing/ hawler medical University MSc in psychiatry nursing and $\mathrm{PhD}$ student.

\section{Funding:}

Hawler medical University by (waiver)

\section{Availability of data and materials:}


Included 100 nurses in hospitals and primary health care centers in Erbil city.

\section{Ethics approval and consent to participate:}

Ethical consideration was provided and supported by college of nursing/ Hawler medical University.

\section{Consent for publication:}

Not applicable.

Competing interests:

The authors having no competing interests.

\section{Consent to participate and ethical} committee:

We have taken permission from ethical and scientific committee in the research center of Hawler Medical University to conduct this study according to approval document No.174 in 17.7.2018 and No.175 in 17.7.2018, and also we have taken verbal acceptance of nurses and health professionals to participate with our study.

\section{Strobe checklist:}

We are ensuring our manuscript reporting adheres to STROBE guidelines for reporting observational research.

\section{References:}

1. NurseTogether. 2020. Are You A Nursing Professional? | Nursetogether. [online] Available at: <http://www.nursetogether.com/tabid/ 102/itemid/1169/Are-You-a-Nursing-

Professional.aspx> [Accessed 11 May 2020].

2. RNAO. Professionalism in Nursing. 2007 Accessed on July 10, 2010 from http://www.rnao.org/Storage/28/2303 _BPG_Professionalism.pdf

3. Salvage J. Etkinliğe Doğru Eylem (Editör: Saadet Ülker), 2. Baskı. Ankara: Aydoğdu Ofset. 1993.
4. Gökçora ï. Profesyonelliğe saygı. Üniversite ve Toplum Dergisi: 2005 5(3).

5. Karamanoğu A, Özer F. Tuğcu A. Denizli ilindeki hastanelerin cerrahi kliniklerinde çalışan hemşirelerin mesleki profesyonelliklerinin değerlendirilmesi. Fırat Tıp Dergisi ; 2009 14(1): 12-17.

6. Taylan S. Özerklik ilkesi çerçevesinde hemşirenin bağımsız rolleri. Çukurova Üniversitesi Sağlık Bilimleri Enstitüsü, Deontoloji ve Tıp Tarihi Anabilim Dalı Yüksek Lisans Tezi, Adana. 2009.

7. Karadağ A. Meslek olarak hemşirelik. Atatürk Üniversitesi Hemşirelik Yüksekokul Dergisi; 2002 5(2):

8. Öktem Ş, Abbasoğlu A, Doğan N. Hemşirelik tarihi, eğitimi ve gelişimi. Ankara Üniversitesi Dikimevi Sağlık Hizmetleri Meslek Yüksekokulu Yıllığı ; 2000. 1.

9. Pavalko, RM. Sociology of occupations and professions. Itasca, IL: F. E. Peacock Publishers, 1971 Inc.

10. Karadağ A, Hisar F, Elbaş Özhan N. Hemşirelikte profesyonelliğe ilişkin davranışsal envanter. Hemşirelik Forumu Dergisi 2004; 7(4): 1422.

11. Karadağ A, Hisar F, Elbaş Özhan N. The level of profesionalism among nurses in Turkey. Journal Of Nursing Scholarship 2007; 39(4): 371-374.

12. Öz F. Sağlık Alanında Temel Kavramlar, 2. Baskı. Ankara: Mattek Matbaacılık; 2010. International J. of Health Services Research and Policy 2017. 2(1):14 -2020

13. Karagözoğlu Ş. Bilimsel bir disiplin olarak hemşirelik. Cumhuriyet Üniversitesi Hemşirelik Yüksekokulu Dergisi 2005; 9(1): 6-14.

14. Erbil N, Bakır A. Meslekte profesyonel tutum envanterinin geliştirilmesi. 
Uluslararası İnsan Bilimleri Dergisi 2009;

6(1) : 291-302.

15. Jamieson, S. Likert scales: how to (ab) use them. Medical Education, 2004, 38(12), 1217-1218.

16. Özlem Doğan YÜKSEKOL1, Meliha ATALAY2, EVALUATION OF PROFESSIONALISM OF NURSES IN THE CITY CENTER OF ELAZIĞ, TURKEY October31,2017, International J. of Health Services Research and Policy 2017, 2(1):14 -20avilable at: (http://dergipark.gov.tr/ijhsrp)

17. Al Banna, D., 2017. Core Professional and Personal Values of Nurses about Nursing in Erbil City Hospitals: A Profession, Not Just Career. Nursing \& Healthcare International Journal, 1(1).

18. Patidar, A., Kaur, J., Sharma, S. and Sharma, N., 2011. Future Nurses' Perception Towards Profession : A Cross Sectional Survey In Punjab State. Nursing and Midwifery Research Journal,, 7 . 


\section{Supplementary Files}

This is a list of supplementary files associated with this preprint. Click to download.

- Tables.pdf 